\title{
Proactive Control of Petri Disease of Grapevine Through Treatment of Propagation Material
}

Paul H. Fourie, Department of Plant Pathology, Stellenbosch University, Private Bag X1, Matieland (Stellenbosch) 7602, South Africa; and Francois Halleen, Disease Management Division, ARC Infruitec-Nietvoorbij, Private Bag X5026, Stellenbosch 7599, South Africa

\begin{abstract}
Fourie, P. H., and Halleen, F. 2004. Proactive control of Petri disease of grapevine through treatment of propagation material. Plant Dis. 88:1241-1245.

Petri disease is a vascular disease associated with decline and dieback of young grapevines. A major means of spread of the causal organisms, Phaeomoniella chlamydospora and Phaeoacremonium spp., is via infected propagation material. Since no curative control measures are known, proactive measures must be taken in grapevine nurseries to manage this disease. To study this aspect, semicommercial trials with naturally infected rootstock material were performed in grapevine nurseries in South Africa. Prior to grafting, rootstocks were treated as follows: 1-h drench in suspensions of benomyl, phosphoric acid, different bacterial and Trichoderma formulations, water, or hot water treated (HWT; $30 \mathrm{~min}$ at $50^{\circ} \mathrm{C}$ ). Grafted cuttings were planted and grown in a greenhouse and two commercial field nurseries and uprooted 8 months later. In instances where rootstocks were treated with benomyl or Trichoderma formulations, the incidences of Phaeomoniella and Phaeoacremonium in grafted cuttings and uprooted nursery vines were significantly lower than that of the water treatment. However, the reduction was most consistent and noteworthy in vines on rootstocks that received HWT prior to grafting. HWT of dormant nursery vines effected a similar reduction in Phaeomoniella and Phaeoacremonium incidence. Rootstock drenches in benomyl and/or Trichoderma formulations could thus be integrated with HWT for the proactive management of Petri disease in grapevine nurseries.
\end{abstract}

Additional keywords: black goo decline, esca, hot water treatment

The fungus Phaeomoniella chlamydospora (syn. Phaeoacremonium chlamydosporum) is the main causal agent of Petri disease (formerly known as black goo decline, brown wood streaking, and young vine decline) of grapevine (19). Petri disease affects mostly 1- to 5-year-old grapevines. External symptoms include stunted growth, interveinal chlorosis, leaf necrosis, decline, and possibly dieback. Dissected vines show a typical black discoloration of the xylem vessels, which is a result of tyloses, gums, and phenolic compounds formed inside these vessels by the host in response to the fungus growing in and around the xylem vessels (19). It is believed that the host is predisposed to the pathogenic phase of this fungus by stress, in particular water stress (8). Blocked xylem vessels accentuate the water stress and lead to insufficient water and nutrient supply to the vegetative plant parts. This consequently leads to symptom expression, which usually occurs during periods of high water demand (19). Furthermore, the

Corresponding author: Paul H. Fourie

E-mail: phfourie@sun.ac.za

Accepted for publication 22 June 2004.

Publication no. D-2004-0908-01R

(C) 2004 The American Phytopathological Society pathogens produce phytotoxic metabolites that contribute to symptom expression (23). Several Phaeoacremonium spp. were also associated with Petri disease, most notably $P$. aleophilum and $P$. inflatipes (19). Even though a pycnidial synanamorph of Phaeomoniella chlamydospora has been observed on grapevines in the field (5) and conidia of P. aleophilum and $P$. inflatipes were trapped or detected in vineyards $(6,16)$, a major means of spread is believed to be via infected propagation material, specifically rootstock material $(9,12,19)$. Whiteman et al. (26) detected DNA of Phaeomoniella chlamydospora at various stages during the grapevine propagation process (hydration tanks, grafting tools, and callusing media). They also detected the pathogen from soil surrounding an infected rootstock mother vine, as did Rooney et al. (20).

Given the large numbers of wounds made to propagation material during the various nursery stages, hygiene and wound protection should be of utmost importance. This is further accentuated by the fact that Phaeomoniella chlamydospora was shown to be a potent pruning wound colonizer (22). Several chemical, biological, and physical strategies are practiced and/or have been studied for hygiene and wound protection during the grapevine propagation process. Chemical strategies mainly involve drenches of propagation material at various stages. Presently, grapevine nurseries in South Africa use a variety of broadspectrum fungicides (e.g., captan, iprodione, 8-hidroxyquinoline sulfate) (18) or quaternary ammonium sterilizing compounds. However, some of these materials were found to be moderately or poorly effective in reducing germination or mycelial growth of Phaeomoniella chlamydospora $(11,14)$. These workers also found that fungicides from the anilopyrimidine, benzimidazole, demethylation inhibitor, and quinone-outside inhibitor classes are very effective in reducing germination and mycelium growth of Phaeomoniella chlamydospora. Di Marco et al. $(3,4)$ noted promising results in the management of esca disease of grapevine (caused by the Petri disease-causing fungi and Fomitiporia punctata) with foliar treatment with the phosphonate chemical, fosetyl-Al. Foliar sprays of phosphonate were also the most effective curative treatment of young grapevines infected with Phaeomoniella chlamydospora (17). Phosphonates showed no fungicidal or fungistatic efficacy $(11,14)$, but Di Marco et al. (3) demonstrated synergism in mixtures of phosphorous acid and resveratrol, a common phytoalexin produced by grapevines, resulting in increased inhibition of these fungi.

Biological strategies involved mainly wound protection agents and soil drenches. Ferreira et al. (7) reported reduced Eutypa lata infection of pruning wounds following wound protection with an isolate of Bacillus subtilis. Protection of grapevine pruning wounds against E. lata with Trichoderma formulations was also reported $(13,15)$, but efficacy against other woundinvading pathogens, such as Phaeomoniella chlamydospora, was uncertain. Fourie et al. (10) demonstrated the growth stimulating attributes of Trichoderma treatments (dips, soil amendments, and drenches with Trichoderma products containing propagules of selected strains of $T$. harzianum) in grapevine nurseries and their marginal reduction of fungi in roots and rootstocks of nursery grapevines, in particular the fungi causing Petri disease (Phaeomoniella chlamydospora and Phaeoacremonium spp.) and black foot rot (Cylindrocarpon spp.).

Hot water treatment (HWT) of propagation material was tested for control of Phaeomoniella chlamydospora and other grapevine trunk pathogens by several re- 
searchers using different methodologies $(2,17,21)$. Variable results were obtained, despite in vitro indications that HWT at $51{ }^{\circ} \mathrm{C}$ effectively prevents conidial germination (27).

The aim of this study was to investigate the effect of various chemical, biological, and physical treatments of naturally infected rootstock cuttings on the infection by the Petri disease pathogens, Phaeomoniella chlamydospora and Phaeoacremonium spp., in a semicommercial nursery trial.

\section{MATERIALS AND METHODS}

Grapevine material. In July 2000, 5,000 cuttings were obtained from a 110 Richter (clone RQ28B) certified rootstock mother block, which was selected on the basis of its age (planted in 1982) and the trunks of the rootstock vines (results not shown). In the following year (July 2001), 5,000 rootstock cuttings were obtained from another certified mother block, cultivar 101-14 Mgt (clone AA26A). This mother block was selected because of the relatively high frequency of the Petri disease-causing pathogens detected in rootstocks from this mother block according to the grapevine diagnostic service at ARC Infruitec-Nietvoorbij (Private Bag X5026, Stellenbosch 7599, South Africa). Cabernet Sauvignon (clone CS46C) was used as the scion cultivar.

Treatments. Prior to grafting, the rootstocks (700 per treatment) were drenched for $1 \mathrm{~h}$ in 50-liter suspensions of either benomyl (Benlate 500WP, 50 g per 50 presence of Petri disease pathogens in the

liters of water), phosphorous acid (Phosguard 400SL, Ocean Agriculture, Muldersdrift, South Africa; $250 \mathrm{ml}$ per 50 liters), Trichoderma harzianum (Trichoflow-T, Agrimm Technologies Ltd., Christchurch, New Zealand; 100 g per 50 liters), Trichoderma + Gliocladium (PHP-mixture T41, T77, T90, T295, and T169, Plant Health Products, Nottingham Rd., South Africa; $10^{6}$ spores per $\mathrm{ml}$ ), Bacillus subtilis (isolate used by Ferreira et al. [7], ARC Infruitec-Nietvoorbij; $10^{6}$ spores per $\mathrm{ml}$; 2000 trial only), an experimental bacterial biofertilizer (Soygro-biofertilizer, Soygro Ltd., Potchefstroom, South Africa; equal proportionate suspension of Azospirillum brasilense, Pseudomonas fluorescens, Bacillus subtilis [200-ml formulation of each per 50 liters] with sodium molybdate/thiram [Mollyflo T], Soygro Ltd.; 400 $\mathrm{ml}$ per 50 liters; 2001 trial only), or tap water as untreated control. Aside from the chemical or biological treatment, one group (700 rootstocks) received HWT (30 min at $50^{\circ} \mathrm{C}$ followed by $30 \mathrm{~min}$ in cold water). Following the various treatments, the rootstocks were air-dried before singlebud Cabernet Sauvignon shoots were omega-grafted onto the treated rootstocks (KWV-Vititec, Suider-Paarl 7624, South Africa). Grafted cuttings from the various treatments were divided into four groups (replicates; 175 grafted cuttings per treatment per replicate), and each group was again divided into four groups $(25+50+$ $50+50$ grafted cuttings per treatment per replicate). The grafted cuttings from the various treatments within each group were randomly stacked in callusing boxes and

Table 1. Mean percent incidence and severity of Petri disease-causing fungi (Phaeomoniella chlamydospora and Phaeoacremonium spp.) isolated from xylem tissue in the base of grapevine rootstocks of grafted and callused cuttings; rootstocks were subjected to various treatments before grafting and subsequent callusing

\begin{tabular}{lccc}
\hline & $\begin{array}{c}\text { No. of } \\
\text { grafted cuttings }\end{array}$ & \multicolumn{2}{c}{ Phaeomoniella and Phaeoacremonium } \\
\cline { 2 - 4 } Treatment $^{\mathbf{x}}$ & Incidence $^{\mathbf{y}}$ & Severity $^{\mathbf{z}}$ \\
\hline 2000-2001 season (110 Richter rootstock) & & \\
Benomyl & 95 & $5.3 \mathrm{ab}$ & $28.9 \mathrm{a}$ \\
Phosphorous acid & 84 & $8.0 \mathrm{ab}$ & $21.7 \mathrm{a}$ \\
Trichoflow & 93 & $11.4 \mathrm{a}$ & $23.0 \mathrm{a}$ \\
PHP mixture & 89 & $5.4 \mathrm{ab}$ & $33.3 \mathrm{a}$ \\
Bacillus & 92 & $3.1 \mathrm{ab}$ & $35.0 \mathrm{a}$ \\
HWT & 93 & $1.2 \mathrm{~b}$ & $20.0 \mathrm{a}$ \\
Water & 91 & $7.7 \mathrm{ab}$ & $25.0 \mathrm{a}$ \\
LSD $(P=0.05)$ & & 9.28 & 23.44 \\
2001-2002 season (101-14 Mgt rootstock) & & \\
Benomyl & 97 & $1.0 \mathrm{a}$ & $80.0 \mathrm{a}$ \\
Phosphorous acid & 97 & $1.0 \mathrm{a}$ & $40.0 \mathrm{ab}$ \\
Trichoflow & 91 & $4.4 \mathrm{a}$ & $23.3 \mathrm{~b}$ \\
PHP mixture & 94 & $2.3 \mathrm{a}$ & $30.0 \mathrm{~b}$ \\
Soygro biofertilizer & 92 & $3.2 \mathrm{a}$ & $33.3 \mathrm{ab}$ \\
HWT & 98 & $1.0 \mathrm{a}$ & $20.0 \mathrm{~b}$ \\
Water & 96 & $3.2 \mathrm{a}$ & $40.0 \mathrm{ab}$ \\
LSD $(P=0.05)$ & & 35 & 49.60 \\
\hline
\end{tabular}

x One-hour drench or hot water treatment (HWT; $30 \mathrm{~min}$ in $50^{\circ} \mathrm{C}$ water) of rootstocks prior to grafting.

${ }^{y}$ Mean incidence (\%) of infected rootstocks. Values within each column followed by the same letter do not differ significantly $(P<0.05)$.

${ }^{\mathrm{z}}$ Mean percentage of colonized xylem segments (five segments per rootstock) in infected rootstocks only. Values within each column followed by the same letter do not differ significantly $(P<0.05)$. allowed to callus following the standard methods for hot callusing used at KWVVititec.

Postcallus ratings. The first group of grafted cuttings ( 25 per treatment per replicate) was taken to the laboratory for the postcallus ratings. Using a 0 to 5 scale, callus formation was visually assessed as the percentage of the circumference of the graft union with visible callus tissue $(0=$ $0 \%, 1=1$ to $25 \%, 2=26$ to $50 \%, 3=51$ to $75 \%, 4=76$ to $99 \%$, and $5=100 \%$ ). Initial shoot growth was determined by measuring the longest shoot. The incidence and severity of infections by Phaeomoniella and Phaeoacremonium spp. in the rootstocks were determined as follows: sections ( $6 \mathrm{~cm}$ long) were cut from the basal end of the rootstocks and surfacedisinfested (30 s in 70\% ethanol, $2 \mathrm{~min}$ in $3.5 \%$ sodium hypochlorite, and $30 \mathrm{~s}$ in $70 \%$ ethanol) and air-dried in a laminar flow cabinet. The sections were split longitudinally, and five small $(1 \times 0.5 \mathrm{~mm})$ xylem segments were cut $\pm 3 \mathrm{~cm}$ from the base of each rootstock and plated on potato dextrose agar medium amended with chloramphenicol at $250 \mathrm{mg} / \mathrm{liter}$. Previous research has shown that this section of the rootstock generally yielded relatively higher frequencies of Phaeomoniella and Phaeoacremonium spp. than other sections (12). Rootstock sections were incubated for 14 to 21 days at $23^{\circ} \mathrm{C}$ under a diurnal light schedule before fungi were microscopically identified. The incidence of Petri disease fungi (Phaeomoniella chlamydospora and Phaeoacremonium spp.) was determined as the mean percentage of rootstocks (25 rootstocks per treatment per replicate) that was infected by these fungi. The severity of infection in infected rootstocks was determined as the mean percentage of xylem segments (five segments per rootstock) that was colonized by these fungi.

Planting. The second and third groups of grafted cuttings (50 grafted cuttings per group per treatment per replicate) were planted in field nurseries in 2000 and 2001 (two separate field nurseries per season). The fourth group was rewaxed, planted in sterile sand-bark mixture in 1-liter nursery bags, and grown in a greenhouse. The experiment was a completely randomized design with seven treatments, four replicates, and three sites. Fungicide and pesticide treatments, irrigation, nutrition, and other cultural practices were done according to the standard nursery or greenhouse guidelines (KWV-Vititec).

Ratings after uprooting. At the end of each growing season (May), nursery and greenhouse vines were uprooted and percentage of certifiable vines (number of certifiable vines [Vine Improvement Association, Paarl 7622, South Africa] as a percentage of the total number of grafted cuttings planted) was calculated. Total root and shoot mass of 25 vines per treatment per replicate per group was determined, 
and 6-cm sections were cut from the base of these vines to determine the incidence and severity of Phaeomoniella and Phaeoacremonium infection as described above.

HWT of dormant nursery vines. The effect of HWT of dormant vines on the incidence of Petri disease pathogens was also tested. The remaining vines from the various treatments were given HWT, and the incidence and severity of infection by Phaeomoniella and Phaeoacremonium in the HWT vines were determined as described above.

Statistical analyses. Callus ratings, root and shoot mass, percentage of certifiable vines, and incidence and severity of Phaeomoniella and Phaeoacremonium infection were subjected to analyses of variance using SAS version 8.1 (SAS Institute, Cary, NC). Student's $t$ least significant difference was calculated at a $5 \%$ significance level to compare treatment means. Data from each season were analyzed separately.

\section{RESULTS}

Postcallus ratings. None of the treatments had a negative influence on callus or initial shoot growth (results not shown). Analyses of variance showed no statisti-

Table 2. Mean percentage of certifiable grafted grapevines on rootstocks that were subjected to various treatments before grafting and subsequent planting in field nurseries and a greenhouse

\begin{tabular}{lcc}
\hline & \multicolumn{2}{c}{ Certifiable vines (\%) } \\
\cline { 2 - 3 } Treatments $^{\mathbf{y}}$ & $\mathbf{2 0 0 0 - 2 0 0 1}$ & $\mathbf{2 0 0 1 - 2 0 0 2}$ \\
\hline Benomyl & $69.4 \mathrm{a}^{\mathrm{z}}$ & $54.7 \mathrm{ab}$ \\
Phosphorous acid & $64.0 \mathrm{a}$ & $57.0 \mathrm{ab}$ \\
Trichoflow & $62.1 \mathrm{a}$ & $53.6 \mathrm{ab}$ \\
PHP mixture & $67.4 \mathrm{a}$ & $51.7 \mathrm{~b}$ \\
Bacillus & $68.1 \mathrm{a}$ & $\ldots$ \\
Soygro biofertilizer & $\ldots$ & $53.2 \mathrm{ab}$ \\
HWT & $67.6 \mathrm{a}$ & $61.5 \mathrm{a}$ \\
Water & $63.6 \mathrm{a}$ & $55.5 \mathrm{ab}$ \\
LSD $(P=0.05)$ & 14.04 & 8.74 \\
\hline
\end{tabular}

y One-hour drench or hot water treatment (HWT; $30 \mathrm{~min}$ in $50^{\circ} \mathrm{C}$ water) of rootstocks prior to grafting.

${ }^{\mathrm{z}}$ Means followed by the same letter do not differ significantly $(P<0.05)$. cally significant differences in the incidence or severity of infection of Phaeomoniella and Phaeoacremonium in the base of the grafted rootstocks (analysis of variance table not shown). Low incidences were recorded from the 110 Richter and 101-14 Mgt rootstocks during the 20002001 and 2001-2002 seasons, respectively (Table 1). Markedly higher incidences were observed in the 110 Richter rootstocks, with the highest incidence $(11.4 \%)$ recorded for the Trichoflow treatment and the lowest for the HWT (1.2\%). However, none of the treatments differed significantly from the water control $(7.7 \%)$.

Ratings after uprooting. Analyses of variance showed significant differences between the percentage of certifiable vines recorded for uprooted vines from the field nurseries and the greenhouse in both seasons $(P=0.0273$ and $P<0.0001$; analysis of variance table not shown). This might be attributed to the generally higher percentage of certifiable vines recorded from vines grown in sterile soil in the greenhouse (results not shown). However, a significant site $\times$ treatment interaction was not observed in either season $(P=0.2374$ and $P=0.2472$ ), and the data were consequently pooled. Significant differences among treatments were observed in the 2001-2002 season only (Table 2), with HWT yielding the highest percentage of certifiable vines $(61.5 \%)$, marginally better than the water control (55.5\%) and significantly better than the vines that were treated with the PHP mixture $(51.7 \%)$. Root and shoot mass results varied, but no meaningful differences were observed (results not shown).

Analyses of variance of the incidence and severity of Phaeomoniella and Phaeoacremonium spp. in the bases of rootstocks of grafted vines grown in field nurseries and greenhouse showed no significant site $x$ treatment interaction in the 2000-2001 season $(P=0.7601$ and 0.2833 , respectively; Table 3 ). Data for this season were consequently pooled, and the mean incidences and severities for each treatment are given in Table 4. HWT proved to be the most effective treatment in reducing incidence $(10.7 \%)$ and severity $(29.3 \%)$ of infection, but none of the treatments reduced the incidence or severity significantly with respect to the water-treated control (15.0 and 44.1\%, respectively). However, HWT of dormant vines after uprooting reduced the incidence (mean $2.8 \%$ ) and severity (mean $27.0 \%$ ) significantly. A significant site $\times$ treatment interaction was observed for the incidences and severities recorded in the 2001-2002 season $(P=0.0014$ and 0.0334 , respectively; Table 3) and the data were thus analyzed separately (Table 5). Markedly higher incidences and severities of Phaeomoniella and Phaeoacremonium were observed in the 101-14 Mgt rootstocks used in this season; 76.0 to $85.5 \%$ and 77.4 to $82.2 \%$, respectively, for the water-treated control. The site $\times$ treatment interaction could be attributed to the varying incidences recorded for the phosphorous acid, Trichoflow, and PHP mixture treatments. The latter two treatments, respectively, caused a 67.6 and $29.4 \%$ reduction in incidence of Phaeomoniella and Phaeoacremonium in the Citrusdal field nursery, a 26.3 and $31.6 \%$ reduction in the greenhouse, but only a 6.9 and $18.6 \%$ reduction in the Piketberg nursery. The phosphorous acid and Soygro biofertilizer treatments yielded incidences similar to or higher than that of the water-treated control. The incidence of Phaeomoniella and Phaeoacremonium in the treated vines was consistently reduced by benomyl (mean reduction of $34.7 \%$ ) and HWT (mean reduction of $93.9 \%$ ). Severity of infection was not an accurate indicator of treatment efficacy and was in general reduced by HWT only.

HWT of dormant nursery vines. HWT of dormant vines after uprooting effected a reduction in incidence and severity of Phaeomoniella and Phaeoacremonium, similar to the reduction observed when HWT was done prior to grafting (Tables 4 and 5). In several of these treatments, Phaeomoniella and Phaeoacremonium could not be detected.

\section{DISCUSSION}

Previous studies have shown that Phaeomoniella and Phaeoacremonium spp. occur in rootstock cuttings at very low

Table 3. Analysis of variance for effects of treatment and site on percent incidence and severity of Petri disease-causing fungi (Phaeomoniella chlamydospora and Phaeoacremonium spp.) isolated from the xylem tissue in the base of rootstocks of uprooted grafted grapevines; rootstocks were subjected to various treatments ${ }^{\mathrm{z}}$ before grafting and subsequent callusing

\begin{tabular}{|c|c|c|c|c|c|c|c|c|c|c|c|c|}
\hline & \multicolumn{6}{|c|}{ Incidence } & \multicolumn{6}{|c|}{ Severity } \\
\hline & \multicolumn{3}{|c|}{$2000-2001$} & \multicolumn{3}{|c|}{ 2001-2002 } & \multicolumn{3}{|c|}{ 2000-2001 } & \multicolumn{3}{|c|}{ 2001-2002 } \\
\hline & df & MS & SL & df & MS & SL & df & MS & SL & df & MS & SL \\
\hline Site & 2 & 47.6 & 0.5731 & 2 & $2,808.3$ & $<0.0001$ & 2 & 398.9 & 0.2568 & 2 & $1,078.9$ & 0.0021 \\
\hline Treatment & 13 & 742.4 & $<0.0001$ & 13 & $9,121.6$ & $<0.0001$ & 11 & 619.0 & 0.0289 & 13 & $2,213.0$ & $<0.0001$ \\
\hline Site $\times$ treatment & 20 & 64.1 & 0.7601 & 20 & 298.8 & 0.0014 & 13 & 351.9 & 0.2833 & 12 & 326.5 & 0.0334 \\
\hline Error & 96 & 85.0 & & 87 & 116.6 & & 61 & 286.9 & & 62 & 158.6 & \\
\hline Corrected total & 131 & & & 122 & & & 87 & & & 89 & & \\
\hline
\end{tabular}

${ }^{\mathrm{z}}$ One-hour drench in benomyl, phosphorous acid, Trichoflow, PHP mixture, Bacillus (2000-2001 only), Soygro biofertilizer (2001-2002 only), and water or hot water treatment (HWT; $30 \mathrm{~min}$ in $50^{\circ} \mathrm{C}$ water) of rootstocks (110 Richter in 2000-2001; 101-14 Mgt in 2001-2002) prior to grafting, or these treatments, each with HWT of the dormant vines after uprooting. 
frequencies $(9,12)$. Results from this study support these findings. Contrary to results by Halleen et al. (12), incidence of these pathogens increased significantly while the grafted vines were growing in field nurseries or in sterile planting media in a greenhouse. Because the increases observed from field nurseries and sterile planting media were similar, we conclude that the major source of inoculum was not from contaminated soil. Increases in the incidence and severity of Phaeomoniella and Phaeoacremonium infection during the field nursery stage can thus be attributed mainly to increased colonization. This observation highlights the need for management strategies that prevent or eradicate infection or contamination of propagation material.

HWT of rootstock cuttings prior to grafting or after uprooting proved to be the only treatment that significantly reduced the levels of Phaeomoniella and Phaeoacremonium. HWT did not eradicate these pathogens from the rootstocks, but it markedly reduced the incidence and severity of infection relative to the water-treated controls. The incidence and severity did not differ significantly from that observed for the other chemical or biological treat-

Table 4. Mean percent incidence and severity of Petri disease infections, caused by Phaeomoniella chlamydospora and Phaeoacremonium spp., in the bases of rootstocks of uprooted grafted grapevines; rootstocks (110 Richter) were subjected to various treatments before grafting and subsequent callusing during the 2000-2001 season

\begin{tabular}{|c|c|c|c|}
\hline \multirow[b]{2}{*}{ Treatment $^{x}$} & \multirow{2}{*}{$\begin{array}{c}\text { No. of } \\
\text { uprooted vines }\end{array}$} & \multicolumn{2}{|c|}{ Phaeomoniella and Phaeoacremonium } \\
\hline & & Incidence $^{\mathrm{y}}$ & Severity ${ }^{\mathrm{z}}$ \\
\hline Benomyl & 296 & $17.3 \mathrm{ab}$ & $44.0 \mathrm{ab}$ \\
\hline Phosphorous acid & 276 & $21.8 \mathrm{a}$ & $43.8 \mathrm{ab}$ \\
\hline Trichoflow & 283 & $23.2 \mathrm{a}$ & $47.0 \mathrm{ab}$ \\
\hline PHP mixture & 276 & $15.5 \mathrm{ab}$ & $37.9 \mathrm{ab}$ \\
\hline Bacillus & 294 & $22.5 \mathrm{a}$ & $47.9 \mathrm{a}$ \\
\hline HWT & 296 & $10.7 \mathrm{bcd}$ & $29.3 \mathrm{ab}$ \\
\hline Water & 269 & $15.0 \mathrm{abc}$ & $44.1 \mathrm{ab}$ \\
\hline Benomyl + HWT & 37 & $1.3 \mathrm{e}$ & $20.0 \mathrm{~b}$ \\
\hline Phosphorous acid + HWT & 76 & $5.5 \mathrm{de}$ & $20.0 \mathrm{~b}$ \\
\hline Trichoflow + HWT & 56 & $6.2 \mathrm{cde}$ & $20.0 \mathrm{~b}$ \\
\hline PHP mixture + HWT & 70 & $4.3 \mathrm{de}$ & $35.0 \mathrm{ab}$ \\
\hline Bacillus + HWT & 49 & $2.4 \mathrm{de}$ & $40.0 \mathrm{ab}$ \\
\hline HWT + HWT & 44 & $0.0 \mathrm{e}$ & $\ldots$ \\
\hline Water + HWT & 101 & $0.0 \mathrm{e}$ & $\ldots$ \\
\hline $\operatorname{LSD}(P=0.05)$ & & 8.84 & 27.50 \\
\hline
\end{tabular}

${ }^{x}$ One-hour drench or hot water treatment (HWT; $30 \mathrm{~min}$ in $50^{\circ} \mathrm{C}$ water) of rootstocks prior to grafting, or these treatments, each with HWT of the dormant vines after uprooting.

${ }^{y}$ Mean incidence (\%) of fungi in rootstocks. Values within each column followed by the same letter do not differ significantly $(P<0.05)$.

${ }^{\mathrm{z}}$ Mean percentage of colonized xylem segments (five segments per rootstock) in infected rootstocks only. Values within each column followed by the same letter do not differ significantly $(P<0.05)$.

ments. When infection levels were determined after uprooting, however, incidence and severity levels were significantly lower than those observed in nursery vines on rootstocks that did not receive HWT before grafting. Furthermore, incidences and severities observed in uprooted nursery vines on rootstocks that received HWT were not substantially higher than those observed prior to planting. These findings thus support the conclusion that increased colonization in HWT rootstocks did not occur. We postulate that HWT, apart from killing these pathogens inside host tissue, also may have induced physiological changes and/or resistance, which could have inhibited the colonization of treated rootstocks by Phaeomoniella and Phaeoacremonium. HWT of uprooted nursery vines resulted in a further reduction of infection. This treatment (for a duration of $15 \mathrm{~min}$ ) was also recommended for the eradication of Phytophthora cinnamomi and Meloidogyne javanica from dormant nursery vines $(1,24)$.

None of the chemical or biological treatments caused a reduction in Phaeomoniella and Phaeoacremonium infection in the treated rootstocks similar to that of HWT. During the 2001-2002 trial, benomyl reduced incidences and severities consistently, whereas Trichoflow and the PHP mixture caused a reduction in the Citrusdal nursery and greenhouse only. Although these Trichoderma products showed potential for combating disease, the results were inconsistent. Likewise, phosphorous acid showed variable results and in some cases even caused an increase in the levels of Phaeomoniella and Phaeoacremonium.

None of the treatments tested were detrimental to vine growth and yield of nurs-

Table 5. Mean percent incidence and severity of Petri disease infections, caused by Phaeomoniella chlamydospora and Phaeoacremonium spp., in the bases of rootstocks of uprooted grafted grapevines; rootstocks (101-14 Mgt) were subjected to various treatments before grafting and subsequent callusing during the 2001-2002 season

\begin{tabular}{|c|c|c|c|c|c|c|}
\hline \multirow[b]{3}{*}{ Treatment $^{\mathrm{x}}$} & \multicolumn{3}{|c|}{ Phaeomoniella and Phaeoacremonium incidence $(\%)^{\mathrm{y}}$} & \multicolumn{3}{|c|}{ Phaeomoniella and Phaeoacremonium severity $(\%)^{z}$} \\
\hline & \multicolumn{2}{|c|}{ Field nursery } & \multirow[b]{2}{*}{ Greenhouse } & \multicolumn{2}{|c|}{ Field nursery } & \multirow[b]{2}{*}{ Greenhouse } \\
\hline & Citrusdal & Piketberg & & Citrusdal & Piketberg & \\
\hline Benomyl & $58.9 \mathrm{~b}$ & $39.1 \mathrm{~b}$ & $55.5 \mathrm{c}$ & $75.8 \mathrm{ab}$ & $55.8 \mathrm{a}$ & $71.0 \mathrm{a}$ \\
\hline Phosphorous acid & $67.4 \mathrm{ab}$ & $76.8 \mathrm{a}$ & $89.0 \mathrm{a}$ & $76.2 \mathrm{ab}$ & $67.2 \mathrm{a}$ & $81.4 \mathrm{a}$ \\
\hline Trichoflow & $27.7 \mathrm{c}$ & $68.7 \mathrm{a}$ & $56.0 \mathrm{c}$ & $59.7 \mathrm{ab}$ & $65.0 \mathrm{a}$ & $78.6 \mathrm{a}$ \\
\hline PHP mixture & $60.4 \mathrm{~b}$ & $60.1 \mathrm{ab}$ & $52.0 \mathrm{c}$ & $69.5 \mathrm{ab}$ & $71.1 \mathrm{a}$ & $78.2 \mathrm{a}$ \\
\hline Soygro biofertilizer & $74.7 \mathrm{ab}$ & $76.9 \mathrm{a}$ & $69.0 \mathrm{a}$ & $70.9 \mathrm{ab}$ & $63.0 \mathrm{a}$ & $77.5 \mathrm{a}$ \\
\hline HWT & $1.0 \mathrm{~d}$ & $11.3 \mathrm{c}$ & $2.0 \mathrm{~d}$ & $20.0 \mathrm{c}$ & $61.3 \mathrm{a}$ & $30.0 \mathrm{bc}$ \\
\hline Water & $85.5 \mathrm{a}$ & $73.8 \mathrm{a}$ & $76.0 \mathrm{a}$ & $80.0 \mathrm{a}$ & $82.2 \mathrm{a}$ & $77.4 \mathrm{a}$ \\
\hline Benomyl + HWT & 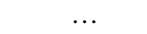 & $0.0 \mathrm{c}$ & $8.5 \mathrm{~d}$ & $\ldots$ & $\ldots$ & $20.0 \mathrm{bc}$ \\
\hline Phosphorous acid + HWT & $0.0 \mathrm{~d}$ & $0.0 \mathrm{c}$ & $3.3 \mathrm{~d}$ & $\ldots$ & $\ldots$ & $20.0 \mathrm{bc}$ \\
\hline Trichoflow + HWT & $\ldots$ & $\ldots$ & $5.8 \mathrm{~d}$ & $\ldots$ & $\ldots$ & $20.0 \mathrm{bc}$ \\
\hline PHP mixture + HWT & $\ldots$ & $3.3 \mathrm{c}$ & $0.0 \mathrm{~d}$ & $\ldots$ & $20.0 \mathrm{~b}$ & \\
\hline Soygro biofertilizer + HWT & & $0.0 \mathrm{c}$ & $7.1 \mathrm{~d}$ & $\ldots$ & $\ldots$ & $37.5 \mathrm{~b}$ \\
\hline HWT + HWT & $0.0 \mathrm{~d}$ & $0.0 \mathrm{c}$ & $3.3 \mathrm{~d}$ & $\ldots$ & $\ldots$ & $20.0 \mathrm{bc}$ \\
\hline Water + HWT & $0.0 \mathrm{~d}$ & $0.0 \mathrm{c}$ & $1.8 \mathrm{~d}$ & $\ldots$ & $\ldots$ & $20.0 \mathrm{bc}$ \\
\hline $\operatorname{LSD}(P=0.05)$ & 19.97 & 25.14 & 11.20 & 18.29 & 31.42 & 16.42 \\
\hline
\end{tabular}

${ }^{x}$ One-hour drench or hot water treatment (HWT; $30 \mathrm{~min}$ in $50^{\circ} \mathrm{C}$ water) of rootstocks prior to grafting, or these treatments, each with HWT of the dormant vines after uprooting.

${ }^{y}$ Mean incidence $(\%)$ of fungi in rootstocks. Values within each column followed by the same letter do not differ significantly $(P<0.05)$.

${ }^{\mathrm{z}}$ Mean percentage of colonized xylem segments (five segments per rootstock) in infected rootstocks only. Values within each column followed by the same letter do not differ significantly $(P<0.05)$. 
ery vines in this semicommercial trial. We can therefore conclude that rootstock drenches in benomyl or the tested Trichoderma formulations and/or HWT can be integrated and implemented on a commercial basis. During the 2001-2002 trial, HWT prior to grafting caused a $10.8 \%$ increase in percentage of certifiable nursery vines grafted onto 101-14 Mgt rootstocks that were severely infected by Phaeomoniella and Phaeoacremonium spp. Wallace et al. (25) reported reduced percentage of certifiable vines due to Phaeomoniella chlamydospora infections, probably due to callus inhibition. Increased percentage of certifiable vines might therefore be attributed to the reduction of Phaeomoniella and Phaeoacremonium infections in the rootstock cuttings.

An integrated strategy for the proactive management of Petri disease in grapevine nurseries can be recommended on the basis of these results. Firstly, the use of certified propagation material of high phytosanitary quality is of the utmost importance. Benomyl or the tested Trichoderma formulations can be used as fungicide in the hydration tanks. This will involve a 1-h drench of the freshly cut rootstock cuttings prior to cold storage and a $1-\mathrm{h}$ drench prior to grafting. HWT after cold storage, prior to grafting is strongly recommended. HWT can be followed by a 1-h cool-down period in cold water amended with benomyl or the tested Trichoderma formulations, thereby substituting the post-cold storage drench. Fourie et al. (10) demonstrated the beneficial effects of root zone drenches with certain Trichoderma products. This practice will result in increased root development and slightly reduced levels of infections caused by the Petri disease pathogens and Cylindrocarpon spp. HWT of the uprooted, dormant nursery vines is recommended based on its reduction of Phaeomoniella and Phaeoacremonium infections, as well as its eradication of certain grapevine root pathogens $(1,24)$. Through the implementation of this management strategy, nursery managers would ensure the production of high-quality grapevines with low levels of infection.

\section{ACKNOWLEDGMENTS}

This work was funded by the Agricultural Research Council and WINETECH and was carried out at the Disease Management Division, ARC Infruitec-Nietvoorbij, Stellenbosch, South Africa.
We acknowledge KWV-Vititec, Zane Sedeman, Henry Allies, Linda Nel, and Carine Vermeulen for technical assistance.

\section{LITERATURE CITED}

1. Barbercheck, M. 1986. Control of Meloidogyne javanica in dormant grapevine nursery stock. Phytophylactica 18:39-40.

2. Crous, P. W., Swart, L., and Coertze, S. 2001. The effect of hot-water treatment on fungi occurring in apparently healthy grapevine cuttings. Phytopathol. Mediterr. 40:S464-S466.

3. Di Marco, S., Mazzullo, A., Calzarano, F., and Cesari, A. 1999. In vitro studies on the phosphorous acid - Vitis stilbenes interaction, and in vivo phosetyl $\mathrm{Al}$ activity towards Phaeoacremonium spp. grapevine wood decay agents. Pages 171-177 in: Modern Selective Fungicides and Antifungal Compounds II. H. Lyr, P. E. Russell, H.-W. Dehne, and H. D. Sisler, eds. Intercept, Andover, UK.

4. Di Marco, S., Mazzullo, A., Calzarano, F., and Cesari, A. 2000. The control of esca: Status and perspectives. Phytopathol. Mediterr. 39:232-240.

5. Edwards, J., and Pascoe, I. G. 2001. Pycnidial state of Phaeomoniella chlamydospora found on Pinot Noir grapevines in the field. Australas. Plant Pathol. 30:67.

6. Eskalen, A., and Gubler, W. D. 2001. Association of spores of Phaeomoniella chlamydospora, Phaeoacremonium inflatipes, and Pm. aleophilum with grapevine cordons in California. Phytopathol. Mediterr. 2001:S429S432.

7. Ferreira, J. H. S., Matthee, F. N., and Thomas, A. C. 1991. Biological control of Eutypa lata on grapevine by an antagonistic strain of $B a$ cillus subtilis. Phytopathology 81:283-287.

8. Ferreira, J. H. S., van Wyk, P. S., and Calitz, F. J. 1999. Slow dieback of grapevine in South Africa: Stress-related predisposition of young vines for infection by Phaeoacremonium chlamydosporum. S.A. J. Enol. Vitic. 20:4346.

9. Fourie, P. H., and Halleen, F. 2002. Investigation on the occurrence of Phaeomoniella chlamydospora in canes of rootstock mother vines. Australas. Plant Pathol. 31:425-426.

10. Fourie, P. H., Halleen, F., van der Vyver, J., and Schreuder, W. 2001. Effect of Trichoderma treatments on the occurrence of decline pathogens in the roots and rootstocks of nursery grapevines. Phytopathol. Mediterr. 40:S473-S478.

11. Groenewald, M., Denman, S., and Crous, P. W. 2000. Fungicide sensitivity of Phaeomoniella chlamydospora, the causal organism of Petri grapevine decline. S.A. J. Enol. Vitic. 21:5961.

12. Halleen, F., Crous, P., and Petrini, O. 2003. Fungi associated with healthy grapevine cuttings in nurseries, with special reference to pathogens involved in the decline of young vines. Australas. Plant Pathol. 32:47-52.

13. Hunt, J. S., Gale, D. S. J., and Harvey, I. C. 2001. Evaluation of Trichoderma as biocontrol for protection against wood-invading fungi implicated in grapevine trunk diseases. Phytopathol. Mediterr. 40:S485.

14. Jaspers, M. V. 2001. Effect of fungicides, in vitro, on germination and growth of Phaeomoniella chlamydospora. Phytopathol. Mediterr. 40:S453-S458.

15. John, S., Scott, E. S., Wicks, T. J., and Hunt, J. S. 2003. Studies of the interactions between Eutypa lata and Trichoderma harzianum. Proc. Int. Workshop Grapevine Trunk Dis. 3rd. Lincoln, New Zealand.

16. Larignon, P., and Dubos, B. 2000. Preliminary studies on the biology of Phaeoacremonium. Phytopathol. Mediterr. 39:184-189.

17. Laukart, N., Edwards, J., Pascoe, I. G., and Nguyen, N. K. 2001. Curative treatments trialed on young grapevines infected with Phaeomoniella chlamydospora. Phytopathol. Mediterr. 40:S459-S463.

18. Marais, P. G., and van der Westhuizen, J. 1978. Ontsmettingsmiddels vir wingerdentmateriaal. Wynboer Tegn. Maart:60-61.

19. Mugnai, L., Graniti, A., and Surico, G. 1999. Esca (Black Measles) and brown woodstreaking: Two old and elusive diseases of grapevines. Plant Dis. 83:404-418.

20. Rooney, S. N., Eskalen, A., and Gubler, W. D 2001. Recovery of Phaeomoniella chlamydospora and Phaeoacremonium inflatipes from soil and grapevine tissues. Phytopathol. Mediterr. 40:S351-S356.

21. Rooney, S. N., and Gubler, W. D. 2001. Effect of hot water treatments on eradication of Phaeomoniella chlamydospora and Phaeoacremonium inflatipes from dormant grapevine wood. Phytopathol. Mediterr. 40:S467-S472.

22. Sparapano, L., Bruno, G., Ciccarone, C., an Graniti, A. 2000. Infection of grapevines by some fungi associated with esca. II. Infection among Phaeoacremonium chlamydosporum, $P$. aleophilum and Fomitiporia punctata. Phytopathol. Mediterr. 39:53-58.

23. Sparapano, L., Bruno, G., and Graniti, A. 2000. Effects on plants of metabolites produced in culture by Phaeoacremonium chlamydosporum, P. aleophilum and Fomitiporia punctata. Phytopathol. Mediterr. 39:169-177.

24. von Broembsen, S., and Marais, P. G. 1978. Eradication of Phytophthora cinnamomi from grapevine by hot water treatment. Phytophylactica 10:25-27.

25. Wallace, J., Edwards, J., Pascoe, I. G., and May, P. 2003. Phaeomoniella chlamydospora inhibits callus formation by grapevine rootstock and scion cultivars. Page 363 in: Proc. Int. Congr. Plant Pathol. 8th. Christchurch, New Zealand.

26. Whiteman, S. A., Jaspers, M. V., Stewart, A., and Ridgway, H. J. 2003. Identification of potential sources of Phaeomoniella chlamydospora in the grapevine propagation process. Page 26 in: Proc. Int. Workshop Grapevine Trunk Dis. 3rd. Lincoln, New Zealand.

27. Whiting, E. C., Khan, A., and Gubler, W. D. 2001. Effect of temperature and water potential on survival and mycelial growth of Phaeomoniella chlamydospora and Phaeoacremonium spp. Plant Dis. 85:195-201. 